\title{
PROPERTIES OF TUBES FROM Zr-1\% Nb ALLOY AFTER THERMOCHEMICAL TREATMENT AND HYDROGENATION
}

\author{
V.S. Trush ${ }^{1}$, V.N. Voyevodin ${ }^{2}$, P.I. Stoev ${ }^{2}$, V.N. Fedirko ${ }^{1}$, A.G. Lukyanenko ${ }^{1}$, \\ M.A. Tikhonovsky', V.A. Panov ${ }^{2}$ \\ ${ }^{1}$ Karpenko Physico-Mechanical Institute of National Academy of Sciences of Ukraine, \\ Lviv, Ukraine; \\ ${ }^{2}$ National Science Center "Kharkov Institute of Physics and Technology”, Kharkiv, Ukraine \\ E-mail: trushvasyl@gmail.com
}

\begin{abstract}
The influence of treatment in controlled gas environments with subsequent hydrogenation on the physical and mechanical characteristics of the $\mathrm{Zr}-1 \% \mathrm{Nb}$ zirconium alloy has been investigated. The surface hardness and the size of the diffusion-hardened layer of the ring-samples cut from fuel tubes from the $\mathrm{Zr}-1 \% \mathrm{Nb}$ alloy after treatment in oxygen- and nitrogen-containing gaseous media with subsequent saturation with hydrogen have been established. The influence of the parameters of the gaseous medium and the modes of thermochemical treatment (TCT) of specimens-rings on the destructive stresses under static load at temperatures of 20 and $380{ }^{\circ} \mathrm{C}$ is shown. It was revealed that treatment in the investigated gas environment increases the resistance to hydrogen saturation and has a positive effect on the long-term strength of ring specimens from the zirconium alloy $\mathrm{Zr}-1 \% \mathrm{Nb}$.
\end{abstract}

\section{INTRODUCTION}

A special place in the nuclear power and nuclear industry is occupied by the problem of creating and improving structural materials: optimization of the structure and increase in operational properties. The structural materials of the core of nuclear reactors include, first of all, zirconium alloys $[1,2]$.

During operation, zirconium cladding materials of fuel elements (fuel tubes) of nuclear reactors are exposed to a corrosive medium in the coolant. Due to the interaction of zirconium with a coolant or a steamwater mixture, hydrogen is released, which is absorbed, in particular, by zirconium fuel tubes [3, 4]. The nearsurface layer and the product as a whole absorb hydrogen, the amount of which depends on factors such as temperature and duration of interaction with the coolant.

Hydrogen accumulated in products impairs the physical and mechanical properties of structural materials and reduces their service life. It should also be noted that at high temperatures, the probability of a steam-zirconium reaction increases, which, in turn, can lead to the accumulation of hydrogen and is explosive in nature. A significant increase in temperature also leads to intensive absorption of oxygen, which is accompanied by oxidation and destruction of fuel tubes [5-8].

Thermochemical treatment (TCT) is one of the effective methods of controlling the structure and characteristics of the near-surface layers of metals, improves their physical and mechanical properties [912]. Thanks to TCT, it is possible to form hydrogen barrier layers. The protective near-surface layer can be obtained by treatment in controlled oxygen- or nitrogencontaining gaseous environments. The control of gasdynamic and temperature-time parameters of TCT provides the formation of various thicknesses and compositions of the modified layer with a wide range of functional properties. It should also be noted that such a layer is an oxide or nitride and a diffusion transition layer, due to which they are strongly adhered to the matrix. Therefore, their detachment from the product is excluded. The development of modes of heat treatment of zirconium alloys in oxygen- and nitrogen-containing gaseous media, which will ensure a decrease in their saturation with hydrogen and do not reduce their mechanical properties, in particular, long-term strength, is an urgent task of modern reactor materials science. The aim of this work is to study the effect of thermochemical treatment in oxygen- and nitrogencontaining gaseous media on the penetration of hydrogen into the surface layer and on the long-term strength of samples cut from the fuel tube of the zirconium alloy $\mathrm{Zr}-1 \% \mathrm{Nb}$.

\section{MATERIALS AND EXPERIMENTAL TECHNIQUE}

The material for research was a Ukrainian-made zirconium alloy $\mathrm{Zr}-1 \% \mathrm{Nb}$ with the following composition: Zr-98.97 wt.\%, Nb-1.03 wt.\%. TCT regimes in gaseous media (oxygen- and nitrogencontaining) were carried out with minimal intrinsic dynamic leakage into the reaction chamber of the furnace (Table 1).

The samples were saturated with gaseous hydrogen ("dry" hydrogenation) at a temperature of $425^{\circ} \mathrm{C}$ and a hydrogen pressure of $0.8 \cdot 10^{5} \mathrm{~Pa}$ (saturation with hydrogen was performed at the KIPT). The concentration of hydrogen in hydrogen-saturated samples was determined by gravimetric and metallographic methods $[13,14]$.

The long-term strength in air at room temperature and at an elevated temperature of $380{ }^{\circ} \mathrm{C}$ on the basis of $100 \mathrm{~h}$ was investigated on specimens-rings $3 \mathrm{~mm}$ wide (Fig. 1,a) with a V-shaped concentrator $0.5 \mathrm{~mm}$ deep, cut symmetrically from both sides of the specimen (see Fig. 1,a). For research, multi-position equipment was used, developed at the Karpenko Physico-Mechanical 
Institute of NAS of Ukraine, which provides identical test conditions for a series of samples.

Table 1

Modes of TCT of zirconium alloy $\mathrm{Zr}-1 \% \mathrm{Nb}$

\begin{tabular}{|c|c|c|c|}
\hline \multirow[b]{2}{*}{ No. } & \multirow[b]{2}{*}{ Processing modes } & \multicolumn{2}{|c|}{$\begin{array}{l}\text { Conditional } \\
\text { designation }\end{array}$} \\
\hline & & TCT & $\begin{array}{c}\text { TCT + } \\
\text { saturation } \\
\text { hydrogen }\end{array}$ \\
\hline \multicolumn{4}{|c|}{ Vacuum annealing } \\
\hline 1 & $\begin{array}{c}\boldsymbol{T}=580^{\circ} \mathrm{C}, \\
\boldsymbol{P}=1.33 \cdot 10^{-2} \mathrm{~Pa}, \tau=3 \mathrm{~h}\end{array}$ & R0 & $\mathrm{R} 0+\mathrm{H}_{2}$ \\
\hline \multicolumn{4}{|c|}{ Oxygenated environment } \\
\hline 2 & $\begin{array}{c}\boldsymbol{T}=580{ }^{\circ} \mathrm{C} \\
\boldsymbol{P}=1.33 \mathrm{~Pa}, \tau=0.5 \mathrm{~h}+ \\
+\boldsymbol{T}=580^{\circ} \mathrm{C} \\
\boldsymbol{P}=1.33 \cdot 10^{-2} \mathrm{~Pa}, \tau=2.5 \mathrm{~h}\end{array}$ & $\mathrm{R} 1$ & $\mathrm{R} 1+\mathrm{H}_{2}$ \\
\hline 3 & $\begin{array}{c}\boldsymbol{T}=580^{\circ} \mathrm{C} \\
\boldsymbol{P}=1.33 \mathrm{~Pa}, \tau=3 \mathrm{~h}\end{array}$ & $\mathrm{R} 2$ & $\mathrm{R} 2+\mathrm{H}_{2}$ \\
\hline \multicolumn{4}{|c|}{ Nitrogen-containing environment } \\
\hline 4 & $\begin{array}{c}\boldsymbol{T}=650^{\circ} \mathrm{C} \\
\boldsymbol{P}=1.33 \cdot 10^{-3} \mathrm{~Pa} \\
\tau=1 \mathrm{~h}+\boldsymbol{T}=580^{\circ} \mathrm{C} \\
\boldsymbol{P}=1.01 \cdot 10^{5} \mathrm{~Pa}, \tau=10 \mathrm{~h}\end{array}$ & R3 & $\mathrm{R} 3+\mathrm{H}_{2}$ \\
\hline 5 & $\begin{array}{c}\boldsymbol{T}=580{ }^{\circ} \mathrm{C} \\
\boldsymbol{P}=1.33 \cdot 10^{-3} \mathrm{~Pa} \\
\tau=1 \mathrm{~h}+\boldsymbol{T}=580{ }^{\circ} \mathrm{C} \\
\boldsymbol{P}=1.01 \cdot 10^{5} \mathrm{~Pa}, \tau=9 \mathrm{~h}\end{array}$ & $\mathrm{R} 4$ & $\mathrm{R} 4+\mathrm{H}_{2}$ \\
\hline
\end{tabular}

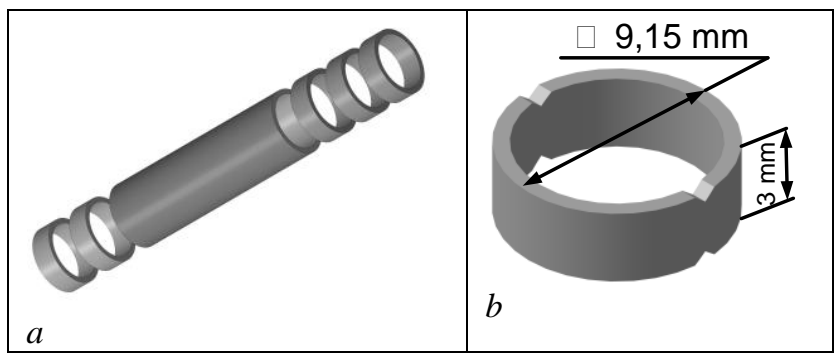

Fig. 1. Schematic diagram of the manufacture of ring specimens for tests under prolonged static load:

a-a diagram of cutting a sample ring from the tube of the fuel element; $b$-applying a concentrator

The following parameters were used to assess the effect of regimes TCT on the material under study: relative increase in surface hardness:

$\delta \mathrm{HV}=\left(\left(\mathrm{HV}^{\text {surf }} \mathrm{HV}^{\text {core }}\right) / \mathrm{HV}^{\text {core }}\right) \times 100 \%$, where $\mathrm{HV}^{\text {surf }}$ titanium surface hardness; $\mathrm{HV}^{\text {core }}$ - hardness of the zirconium core, and the depth of the hardened layer $l, \mu \mathrm{m}$. The microhardness of the surface and the distribution of microhardness over the cross section of the samples were determined on a PMT-3M device with a load on the indenter of $0.49 \mathrm{~N}$.

\section{RESULTS AND ITS DISCUSSION}

Dissolution of interstitial elements (oxygen, nitrogen) in zirconium alloys is associated with distortion of the crystal lattice, as a result of which the hardness increases significantly. Therefore, an increase in the hardness of the near-surface layer indicates that, as a result of thermochemical treatment, the near- surface layer has been enriched with interstitial elements (Table 2, Fig. 2).

Table 2

Characteristics of samples-rings of $\mathrm{Zr}-1 \% \mathrm{Nb}$ alloy after various treatments

\begin{tabular}{|c|c|c|c|c|}
\hline $\begin{array}{c}\text { TCT mode / } \\
\text { + saturation } \\
\text { hydrogen }\end{array}$ & $\begin{array}{c}\text { Hardness } \\
\text { surfaces, } \\
\mathrm{HV}^{\text {surf }}\end{array}$ & $\begin{array}{c}\text { Hardness } \\
\text { matrices, } \\
\mathrm{HV}^{\text {core }}\end{array}$ & $\begin{array}{c}\text { Growth } \\
\text { hardness } \\
\Delta \mathrm{HV}\end{array}$ & $\begin{array}{c}\text { The size } \\
\text { hardened } \\
\text { layer } l, \\
\mu \mathrm{m}\end{array}$ \\
\hline $\mathrm{R} 0 / \mathrm{R} 0+\mathrm{H}_{2}$ & $\begin{array}{c}260 \pm 25 / \\
180 \pm 20\end{array}$ & $\begin{array}{c}170 \pm 15 / \\
175 \pm 10\end{array}$ & $90 / 5$ & $\begin{array}{c}15 \ldots 19 / \\
20 \ldots 23\end{array}$ \\
\hline $\mathrm{R} 1 / \mathrm{R} 1+\mathrm{H}_{2}$ & $\begin{array}{c}275 \pm 20 / \\
175 \pm 20\end{array}$ & $\begin{array}{c}170 \pm 15 / \\
165 \pm 10\end{array}$ & $105 / 10$ & $\begin{array}{c}22 \ldots .27 / \\
29 \ldots 33\end{array}$ \\
\hline $\mathrm{R} 2 / \mathrm{R} 2+\mathrm{H}_{2}$ & $\begin{array}{c}310 \pm 25 / \\
210 \pm 20\end{array}$ & $\begin{array}{c}170 \pm 15 / \\
165 \pm 10\end{array}$ & $140 / 45$ & $\begin{array}{c}19 \ldots 24 / \\
24 \ldots 32\end{array}$ \\
\hline $\mathrm{R} 3 / \mathrm{R} 3+\mathrm{H}_{2}$ & $\begin{array}{c}315 \pm 15 / \\
210 \pm 15\end{array}$ & $\begin{array}{c}170 \pm 15 / \\
165 \pm 15\end{array}$ & $145 / 45$ & $\begin{array}{c}34 \ldots 39 / \\
36 \ldots 43\end{array}$ \\
\hline $\mathrm{R} 4 / \mathrm{R} 4+\mathrm{H}_{2}$ & $\begin{array}{c}320 \pm 15 / \\
185 \pm 20\end{array}$ & $\begin{array}{c}170 \pm 15 / \\
180 \pm 10\end{array}$ & $150 / 5$ & $\begin{array}{c}32 \ldots 37 / \\
23 \ldots 37\end{array}$ \\
\hline
\end{tabular}

According to the research results, nitriding by the mode (R3) in relation to vacuum annealing (R0) and oxidation (R1 and R2) better protects the near-surface layer from hydrogen penetration (Fig. 3).

The distribution of hardness in the near-surface layer of the test specimens-rings after saturation with hydrogen differs when compared with the corresponding treatments: in a vacuum, oxygen- or nitrogen-containing medium (see Fig. 2). Hydrogen saturation significantly reduces the hardness in the subsurface layer. The approximate hydrogen content in the sample rings made of the $\mathrm{Zr}-1 \% \mathrm{Nb}$ alloy after various thermochemical treatment and saturation with hydrogen was as follows (ppm): $\left(\mathrm{R} 0+\mathrm{H}_{2}\right)-712$; $(\mathrm{R} 1+$ $\left.\mathrm{H}_{2}\right)-617 ;\left(\mathrm{R} 2+\mathrm{H}_{2}\right)-471 ;\left(\mathrm{R} 3+\mathrm{H}_{2}\right)-188 ;(\mathrm{R} 4+$ $\left.+\mathrm{H}_{2}\right)-890$ (see Fig. 3).

According to the experimentally obtained results, the 100-hour long-term strength of the samples-rings saturated with hydrogen (Fig. 4) at room temperature after all regimes of TCT exceeds the indices of the samples not saturated with hydrogen (see Fig. 4).

The properties of the samples-rings saturated with hydrogen have some differences among themselves (see Fig. 4). Fracture of sample rings made of $\mathrm{Zr}-1 \% \mathrm{Nb}$ alloy saturated with hydrogen occurs in the stress range 490...510 MPa (see Fig. 4), which is 10 times narrower than for ring samples not saturated with hydrogen, which are destroyed upon exposure for $100 \mathrm{~h}$ in air at room temperature at stresses of $400 \ldots 600 \mathrm{MPa}$ (see Fig. 4).

An increase in the test temperature of the ring specimens to the operating temperature $\left(380{ }^{\circ} \mathrm{C}\right)$ by $\sim 10 \mathrm{MPa}$ (see Fig. 4,b) expanded the range of breaking stresses of the ring specimens saturated with hydrogen when held for $100 \mathrm{~h}$ in air. When comparing the longterm strength of ring specimens at a temperature $\left(380^{\circ} \mathrm{C}\right)$ after different regimes of CTT and those that are unsaturated with hydrogen (see Fig. 4), it can be seen that hydrogen levels the difference in this characteristic, since the dependences of the long-term strength of hydrogen-saturated ring specimens are located among the dependences of the long-term strength of the specimens - rings not saturated with hydrogen. 


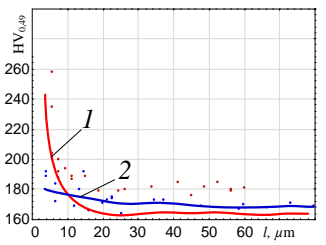

$a$

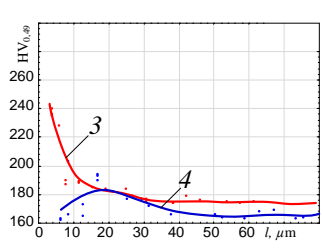

$b$

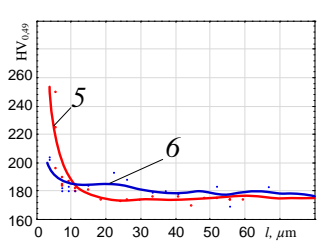

C
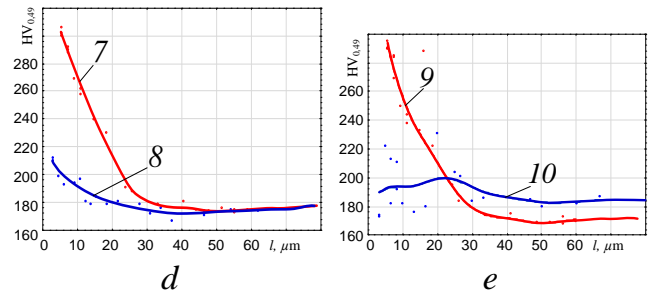

Fig. 2. Distribution of hardness in the near-surface layer of specimens-rings made of $\mathrm{Zr}-1 \% \mathrm{Nb}$ alloy after treatment modes: curve $1-\mathrm{RO} ; 2-\mathrm{RO}+\mathrm{H}_{2} ; 3-\mathrm{R} 1 ; 4-\mathrm{R} 1+\mathrm{H}_{2} ; 5-\mathrm{R} 2 ; 6-\mathrm{R} 2+\mathrm{H}_{2} ; 7-\mathrm{R} 3 ; 8-\mathrm{R}_{3}+\mathrm{H}_{2}$; $9-\mathrm{R} 4 ; 10-\mathrm{R} 4+\mathrm{H}_{2}$

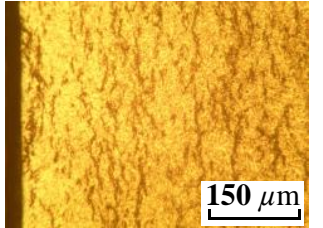

$a$
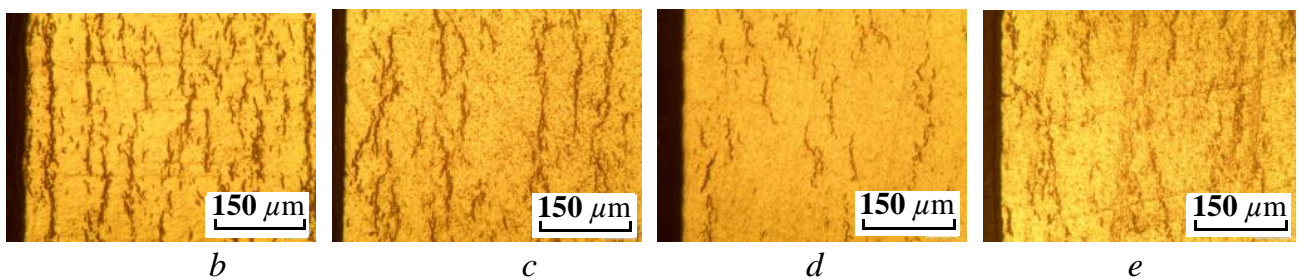

Fig. 3. The structure of the near-surface layer as a result of saturation with hydrogen after treatment modes: $a-\mathrm{RO}+\mathrm{H}_{2} ; b-\mathrm{Rl}+\mathrm{H}_{2} ; \mathrm{c}-\mathrm{R} 2+\mathrm{H}_{2} ; d-\mathrm{R} 3+\mathrm{H}_{2} ; e-\mathrm{R} 4+\mathrm{H}_{2}$
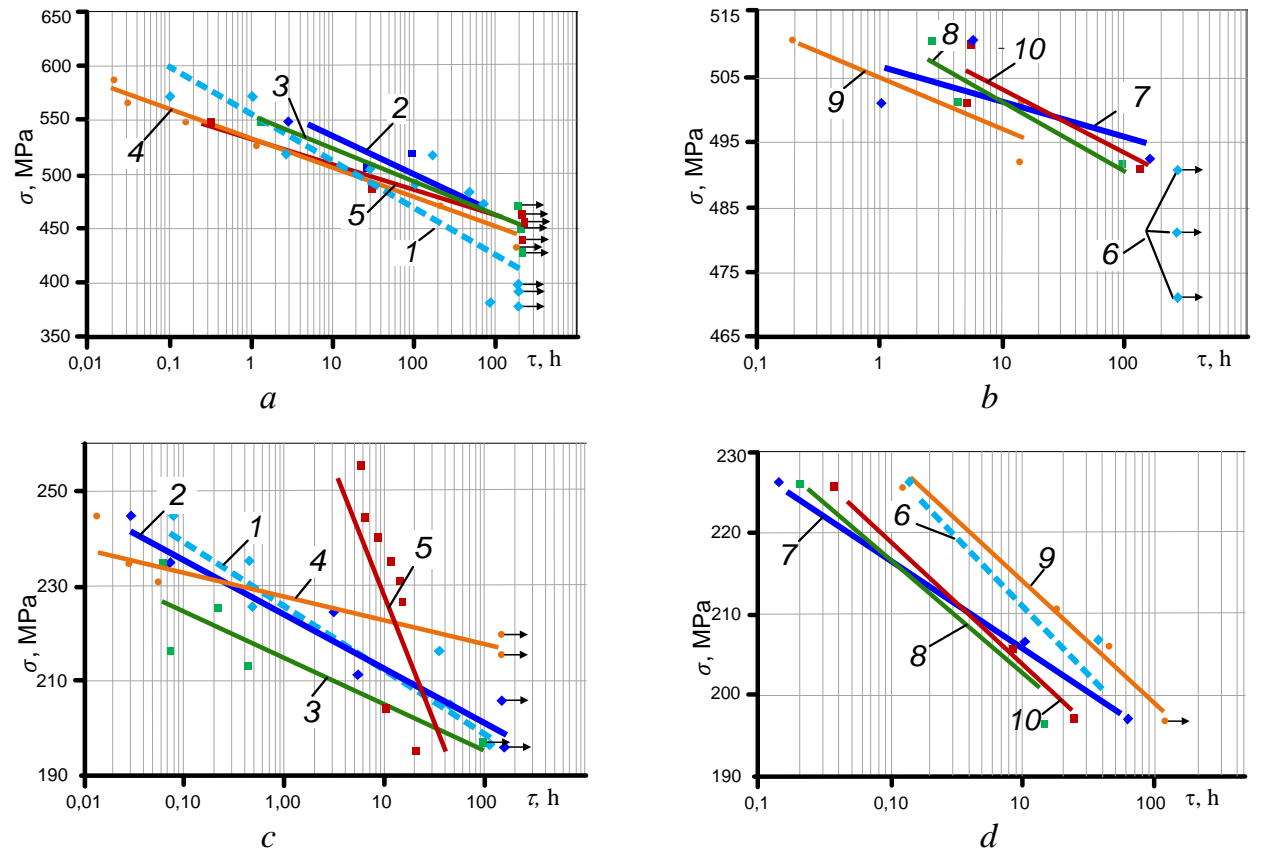

Fig. 4. Long-term strength of samples-rings made of $\mathrm{Zr}-1 \% \mathrm{Nb}$ alloy when exposed to air at room temperature $(a, b)$ and at $T=380^{\circ} \mathrm{C}(c, d)$ after different processing modes:

$1-R 0 ; 2-R 1 ; 3-R 2 ; 4-R 3 ; 5-R 4 ; 6-R O+H_{2} ; 7-R 1+H_{2} ; 8-R 2+H_{2} ; 9-R 3+H_{2} ; 10-R 4+H_{2}$

The long-term strength of ring specimens saturated with hydrogen (mode $\mathrm{R} 3+\mathrm{H}_{2}$ ) exceeds the long-term strength of ring specimens saturated with hydrogen after other pretreatment modes.

\section{CONCLUSIONS}

As a result of experimental studies and analysis of their results, it was established:

- saturation with hydrogen leads to a decrease in the hardness of the surface layer of the $\mathrm{Zr}-1 \% \mathrm{Nb}$ alloy thermochemically treated in oxygen- and nitrogencontaining media;

- treatment of zirconium alloy $\mathrm{Zr}-1 \% \mathrm{Nb}$ in oxygenand nitrogen-containing media increases the resistance to hydrogen saturation;

- saturation with hydrogen of both oxidized and nitrided zirconium alloy $\mathrm{Zr}-1 \% \mathrm{Nb}$ has a positive effect on the resistance to fracture under static load at room temperature;

- saturation with hydrogen of the nitrided zirconium alloy $\mathrm{Zr}-1 \% \mathrm{Nb}$ makes it possible to increase the static fracture stress at a temperature of $T=380{ }^{\circ} \mathrm{C}$ relative to processing in vacuum.

\section{REFERENCES}

1. C. Lemaignan and A.T. Motta. Zirconium Alloys in Nuclear Applications // Materials Science and Technology. Nuclear Materials. 2006, v. 10 B, Part 2, p. 2-51.

2. N.A. Azarenkov, L.A. Bulavin, I.I. Zalyubovsky, V.G. Kirichenko, I.M. Neklyudov, B.A. Shilyaev. Nuclear energy. Chapter 2. Nuclear Energy: Textbook. Kh.: "KhNU named after V.N. Karazin", 2012, 535 p. 
3. A.S. Zaimovsky, A.V. Nikulina, N.G. Reshetnikov. Zirconium alloys in nuclear power M.: "Energoatomizdat", 1994, 256 p.

4. A.T. Motta, L. Capulongo, L.Q. Chen, M.N. Cinbiz, M. Daymond, D.A. Koss, M. Zikry. Hydrogen in zirconium alloys: A review // Journal of Nuclear Materials. 2019, v. 518, p. 440-460.

5. A. Shmakov, B. Kalin, E. Smirnov. Hydrogen in zirconium alloys. Hydride embrittlement and destruction of zirconium materials. LAP Lamberg Academic Publishing ist ein der. Deutschland, 2005, $193 \mathrm{p}$.

6. C. Anghel. Modified oxygen and hydrogen transport in Zr-based oxides: Doctoral Thesis Division of Corrosion Science Department of Materials Science and Engineering Royal Institute of Technology. Stockholm, Sweden, 2006, 256 p.

7. A.S. Zaimovsky, A.V. Nikulina, N.G. Reshetnikov. Zirconium alloys in nuclear power. M.: "Energoatomizdat", 1994, 256 p.

8. B. Cox. Some thoughts on the mechanisms of inreactor corrosion of zirconium alloys // Journal of Nuclear Materials. 2005, v. 336, issue 2-3, p. 331-368.

9. Arthur Hellouin de Menibus, Quentin Auzoux, Ousmane Dieye, Pascal Berger, Sophie Bosonnet, et al. Formation and characterization of hydride blisters in Zircaloy 4 cladding tubes // Journal of Nuclear Materials. 2014, v. 449, p. 132-147.
10. V.M. Fedirko, O.H. Luk'yanenko, V.S. Trush. Solid-Solution Hardening of the Surface Layer of Titanium Alloys. Part 1. Effect on Mechanical Properties // Metal Science and Heat Treatment. 2014, v. 56, issue 7-8, p. 368-373.

11. V.M. Fedirko, O.H. Luk'yanenko, V.S. Trush, P.I. Stoev, M.A. Tikhonovsky. Effect of Thermochemical Treatment in Regulated Gas Media on the Thermal Resistance of $\mathrm{Zr} 1 \% \mathrm{Nb}$ alloy // Materials Science. 2016, v. 52, issue 2, p. 209-215.

12. V.S. Trush, V.N. Fedirko, A.G. Luk'yanenko, M.A. Tikhonovsky, P.I. Stoev. Influence of thermochemical treatment on properties of tubes from $\mathrm{Zr}-1 \mathrm{Nb}$ alloy // Problems of Atomic Science and Technology. 2018, N 2(114), p. 70-75.

13. R.S. Daum, Y.S. Chu, A.T. Motta. Identification and quantification of hydride phases in Zircaloy-4 cladding using synchrotron X-ray diffraction // Journal of Nuclear Materials. 2009, v. 392, N 3, p. 453-464.

14. T.P. Chernyaeva, V.M. Gritsina, V.S. Krasnorutsky, A.P. Redkina, I.A. Petelguzov, E.A. Slabospitskaya. Influence of temperature regime and stress state on reorientation of hydrides in fuel element cladding made of $\mathrm{Zr} 1 \% \mathrm{Nb} / /$ PAST. Series "Vacuum, Pure materials, Superconductors”. 2018, N 1(113), p. 189-202.

\title{
СВОЙСТВА ТВЭЛЬНЫХ ТРУБОК ИЗ СПЛАВА Zr-1\% Nb ПОСЛЕ ТЕРМОХИМИЧЕСКОЙ ОБРАБОТКИ И НАВОДОРОЖИВАНИЯ
}

\author{
В.С. Труи, В.Н. Воеводин, П.И. Стоев, В.Н. Федирко, \\ А.Г. Лукьяненко, М.А. Тихоновский, В.А. Панов
}

Исследовано влияние термохимической обработки в контролируемых газовых средах с последующим наводороживанием на физико-механические характеристики циркониевого сплава $\mathrm{Zr}-1 \% \mathrm{Nb}$. Установлены твердость поверхности и размер диффузионно-упрочненного слоя образцов-колец, вырезанных из твэльных трубок из сплава $\mathrm{Zr}-1 \% \mathrm{Nb}$ после обработки в кислород- и азотсодержащих газовых средах с последующим насыщением водородом. Показаны влияния параметров газовой среды и режимов термохимической обработки образцов-колец на напряжения разрушения при статической нагрузке при температурах 20 и $380{ }^{\circ} \mathrm{C}$. Выявлено, что обработка в исследованных газовых средах повышает сопротивляемость насыщению водородом и положительно влияет на длительную прочность образцов-колец из циркониевого сплава $\mathrm{Zr}-1 \% \mathrm{Nb}$.

\section{ВЛАСТИВОСТІ ТВЕЛЬНИХ ТРУБОК ЗІ СПЛАВУ Zr-1\% Nb ПІСЛЯ ТЕРМОХІМІЧНОЇ ОБРОБКИ ТА НАСИЧЕННЯ ВОДНЕМ}

\author{
В.С. Труи, В.М. Воєводін, П.І. Стоєв, В.М. Федірко, \\ О.Г. Лук'яненко, М.А. Тихоновський, В.А. Панов
}

Досліджено вплив термохімічної обробки в контрольованих газових середовищах 3 наступним насиченням воднем на фізико-механічні характеристики цирконієвого сплаву $\mathrm{Zr}-1 \% \mathrm{Nb}$. Визначено твердість поверхні і розмір дифузійно-зміцненого шару зразків-кілець, вирізаних з твельних трубок сплаву $\mathrm{Zr}-1 \% \mathrm{Nb}$ після обробки в кисне- і азотовмісних газових середовищах, а також з наступним насиченням воднем. Показано вплив параметрів газового середовища і режимів термохімічної обробки зразків-кілець на руйнівні напруження за статичного тривалого навантаження за температурах 20 і $380{ }^{\circ} \mathrm{C}$. Виявлено, що обробка в дослідженому газовому середовищі підвищує опірність насиченню воднем і позитивно впливає на тривалу міцність зразків-кілець з цирконієвого сплаву $\mathrm{Zr}-1 \% \mathrm{Nb}$. 